\title{
Stability of a monovalent rotavirus vaccine after exposure to different temperatures observed in KwaZulu-Natal, South Africa
}

\author{
Osaretin Emmanuel Asowata, Olubisi Titilayo Ashiru, A Willem Sturm, Prashini Moodley
}

Department of Medical Microbiology, Nelson R Mandela School of Medicine, University of KwaZulu-Natal.

\begin{abstract}
Background: Rotavirus infection and its associated hospitalization of children less than 5 years old in middle- and low-income countries remains a public health challenge. We hypothesized that the Rotarix ${ }^{\circledR}$ potency is affected by non-optimal temperatures which translates into reduced vaccine effectiveness in these settings.

Objective: To assess the effect of non-optimal temperatures on the potency of the Rotarix ${ }^{\circledR}$ vaccine in South Africa.

Methods: Rotarix ${ }^{\circledR}$ vaccine was exposed to temperatures reflecting breaches in the cold chain. Vero cells (ATCC CCL-81) grown in a 24-well tissue culture plates were infected with Rotarix ${ }^{\circledR}$ vaccine viruses after exposure to non-optimal temperatures and the potency of the vaccine was determined using the plaque assay.

Results: Exposure of the Rotarix ${ }^{\circledR}$ vaccine to seasonal temperatures in KwaZulu-Natal for 6 hours and to extreme temperatures of $40^{\circ} \mathrm{C}$ for 72 hours as well as to $-20^{\circ} \mathrm{C}$ and $-80^{\circ} \mathrm{C}$ for 12 hours did not affect the potency of the vaccine beyond its expected standard of $>7 \times 10^{5} \mathrm{PFU} / \mathrm{ml}$.

Conclusion: This study revealed that the Rotarix ${ }^{\circledR}$ vaccine remains potent even after exposure to non-optimal temperatures. However, this study only explored the effect of a constant 'adverse' temperature on vaccine potency and not the effect of temperature fluctuations.

DOI: https://dx.doi.org/10.4314/ahs.v19i2.22

Cite as: Asowata OE, Ashiru OT, Sturm AW, Moodley P. Stability of a monovalent rotavirus vaccine after exposure to different temperatures observed in KwaZulu-Natal, South Africa. Afri Health Sci.2019;19(2): 1993-1999. https:/ / dx.doi.org/ 10.4314/ abs.v19i2.22
\end{abstract}

\section{Introduction}

Based on data emanating from studies on the role of rotavirus in the burden of disease $e^{1,2}$ and local safety and efficacy trials of the rotavirus vaccine ${ }^{3}$, South Africa decided as the first African country to include the monovalent rotavirus vaccine $\left(\right.$ Rotarix ${ }^{\circledR}$, GlaxoSmithKline Biologicals, Rixensart, Belguim) in its national immunization programme, starting in $2008^{4}$. The vaccination consists of two-doses, administered orally at 6 and 14 weeks of age, simultaneously with other vaccines included in the expanded programme on immunization (EPI). The vac-

\section{Corresponding author:}

Osaretin Emmanuel Asowata,

Department of Medical Microbiology,

Nelson R Mandela School of Medicine,

University of KwaZulu-Natal

Email: osemas2@gmail.com cine coverage increased rapidly since 2009 and by 2010, about $67 \%$ of children under a year old had received a complete schedule of Rotarix ${ }^{\circledR}$ immunization. The vaccine coverage rate has since increased to more than $90 \%$ in some provinces ${ }^{5}$. However, rotavirus prevalence and its associated hospitalization inSouth Africa including KwaZulu-Natal (KZN) province ${ }^{6}$ has raised questions regarding the effectiveness of this vaccine. To ensure that children receive potent and effective vaccines, the vaccine has to be stored at the optimum temperatures while in storage and on transit. However, accidental or inevitable exposure of this vaccine to heat or freezing temperature while in storage or in transit can result in loss of potency as reported previously by Matthias et $\mathrm{al}^{7}$. The possibility of vaccine exposure to non-optimal temperatures was considered as a factor responsible for the reduced effectiveness of the rotavirus vaccine in middle- and low-income countries. These countries are often characterized by poor road networks and inadequate electricity supply. Poor road networks can expose vaccines to non-optimal

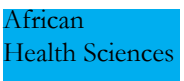

(C) 2019 Asowata et al. Licensee African Health Sciences. This is an Open Access article distributed under the terms of the Creative commons Attribution License (https://creativecommons.org/licenses/BY/4.0), which permits unrestricted use, distribution, and reproduction in any medium, provided the original work is properly cited. 
temperatures in transit while inadequate electricity supply can also expose the vaccines to temperature fluctuations during storage.

The World Health Organization (WHO) recommended that all vaccines except that for oral polio be kept at 2 to $8^{\circ} \mathrm{C}$ during in-country distribution ${ }^{8}$. However, a poorly maintained cold chain system may expose vaccines to non-optimal temperatures ranging from hot to freezing. Rotavirus vaccine is listed as being affected by cold chain failure ${ }^{8-12}$. Vaccine cold-chain challenges are more frequently seen in low income countries in comparison to high income countries. Consequently, loss of potency may be responsible for the reduced effectiveness of the rotavirus vaccine observed in middle- and low-income countries. We assessed the effect of non-optimal storage temperature on the potency of the monovalent rotavirus vaccine.

\section{Methods}

The effect of temperature on the potency of the Rotarix ${ }^{\circledR}$ vaccine was studied. The vaccine was obtained from the central pharmaceutical store of the KwaZulu-Natal Department of Health (DOH). Vaccines were exposed to the average temperatures experienced over the different seasons in KwaZulu-Natal province. The potency was evaluated at $0,1,2,3,4,5$ and 6 hours. The average seasonal temperatures during 2005 till 2015 were $24^{\circ} \mathrm{C}$ in spring, $27.3^{\circ} \mathrm{C}$ in summer, $25.7^{\circ} \mathrm{C}$ in autumn and $23.3^{\circ} \mathrm{C}$ in winter ${ }^{13}$. The vaccines were also exposed to temperatures of $-20^{\circ} \mathrm{C}$ and $-80^{\circ} \mathrm{C}$ for 12 hours and to $40^{\circ} \mathrm{C}$ for up to 72 hours. A digital oven and freezers were used to simulate vaccine exposure to heat and freezing temperatures respectively. The potency of vaccines stored at the advised temperature of 2 to $8^{\circ} \mathrm{C}$ was used as the reference standard.

To quantify the vaccine virus after exposure to the different temperatures, the plaque assay described by Smith et $\mathrm{al}^{14}$, was used with some modifications. Vero cells (ATCC CCL-81) were seeded in wells of a 24-well tissue culture plate at a density of $1 \times 10^{6}$ cells $/ \mathrm{ml}$ in a volume of $500 \mu \mathrm{l}$. The culture medium used was Eagle's minimum essential medium (EMEM) supplemented with 1\% HEPES, 1\%
L-glutamate and 10\% heat-inactivated fetal bovine serum (FBS). The plates were incubated at $37^{\circ} \mathrm{C}$ in $5 \% \mathrm{CO}_{2}$ till confluent. The vaccine reference standard and test samples were diluted 1:10 in trypsin/PBS (1:60) and a 1:10 dilution in PBS without trypsin. Eight ten-fold serial dilutions (10-1 to 10-8) were made of each of the trypsinized test samples in EMEM with HEPES and L-glutamate. The dilutions were vortexed for 15 seconds and incubated at room temperature $\left(25^{\circ} \mathrm{C}\right)$ for 30 minutes prior to infection.

The culture media was aspirated from the confluent Vero cell monolayer and the cells were washed twice with warm PBS. Vaccine virus infection was performed by inoculating $200 \mu \mathrm{l}$ of each sample into the wells in triplicate. The plates were then placed in a $37^{\circ} \mathrm{C}$ incubator with $5 \% \mathrm{CO}_{2}$ for 1 hour. The media was replaced with an agar overlay which contains $1 \mathrm{ml}$ of $0.1 \%$ agarosein EMEM with $2 \%$ FBS and $1 \%$ glutamate. The agarose was allowed to solidify for 15 minutes at room temperature after which the plates were transferred to a $37^{\circ} \mathrm{C}$ incubator with $5 \%$ $\mathrm{CO}_{2}$ until plaques were formed. When plaques became visible, the monolayers were fixed by dispensing $1 \mathrm{ml}$ of $3.6 \%$ formalin on the agar overlay followed by incubation at room temperature for 1 hour. Thereafter, the formalin and agarose were discarded under running water. The monolayers were stained for 3 minutes with crystal violet, washed with running water and air dried. The plaques were counted under an inverted light microscope (Olympus, Tokyo, Japan) at 400x magnification [Figure 1 (a)and (b)]. The concentration of the initial viral suspension in plaque forming unit per milliliter $(\mathrm{PFU} / \mathrm{ml})$ was calculated as: $\mathrm{PFU} / \mathrm{ml}=$ number of plaques $\mathrm{x}$ dilution factor $\mathrm{x}$ volume of inoculum per plate.

According to the manufacturer of the Rotarix ${ }^{\circledR}$ vaccine, the vaccine is potent when it is greater than or equal to $10^{6}$ of $50 \%$ cell culture infective dose (Potency $>10^{6}$ CCID50). To convert the CCID50 to plaque forming unit per milliliter $(\mathrm{PFU} / \mathrm{ml})$, we applied the Poisson distribution $(\mathrm{P}(\mathrm{k})=\mathrm{e}-\mathrm{m} \times \mathrm{m} \mathrm{k} / \mathrm{k})$ and in summary $\mathrm{PFU} / \mathrm{ml}=0.7$ $x$ CCID50. Therefore, $10^{6}$ CCID50 $=0.7 \times 10^{6} \mathrm{PFU} / \mathrm{ml}$ $=7 \times 10^{5} \mathrm{PFU} / \mathrm{ml}$. Therefore, the vaccine should have a minimum potency $>7 \times 10^{5} \mathrm{PFU} / \mathrm{ml}$. 
We compared the potency of each of the vaccines exposed todifferent temperatures to that of our reference standard and to the acceptable potency according to the vaccine manufacturer.

\section{Results}

On receipt of the vaccine from the central pharmacy store, the potency ranged between 5.2- $6.8 \times 10^{10} \mathrm{PFU} /$ $\mathrm{ml}$ with an average of $5.8 \times 10^{10} \mathrm{PFU} / \mathrm{ml}$, represented by the horizontal line in figure 2 and 3 . The potency of the vaccines after exposure to the average seasonal temperatures in $\mathrm{KZN}$ is shown in figure 2. At all temperatures the values obtained were above the minimum potency of $7 \mathrm{x}$
$10^{5} \mathrm{PFU} / \mathrm{ml}$ as per manufacturer's guidelines. However, these temperatures seem to have an effecton the vaccine potency as most of the values were less than pre-exposure to the seasonal temperatures except those exposed to the average temperature of the autumn season. Exposure to extreme temperatures of $40^{\circ} \mathrm{C}$ for 3 to 72 hours (Figure 3) did not decrease the potency of the vaccine below the minimum advised value. However, we observed a gradual reduction in potency as the duration of exposure increases. The vaccine potencies after exposure to $-20 \mathrm{oC}$ and $-80 \mathrm{oC}$ for 12 hours was $3.5 \times 10^{10} \mathrm{PFU} / \mathrm{ml}$ and $3.0 \times 10^{10}$ $\mathrm{PFU} / \mathrm{ml}$ respectively. Although these potencies were less than the potency of the optimally stored vaccines, it was higher than the manufacturer's minimum advised value.

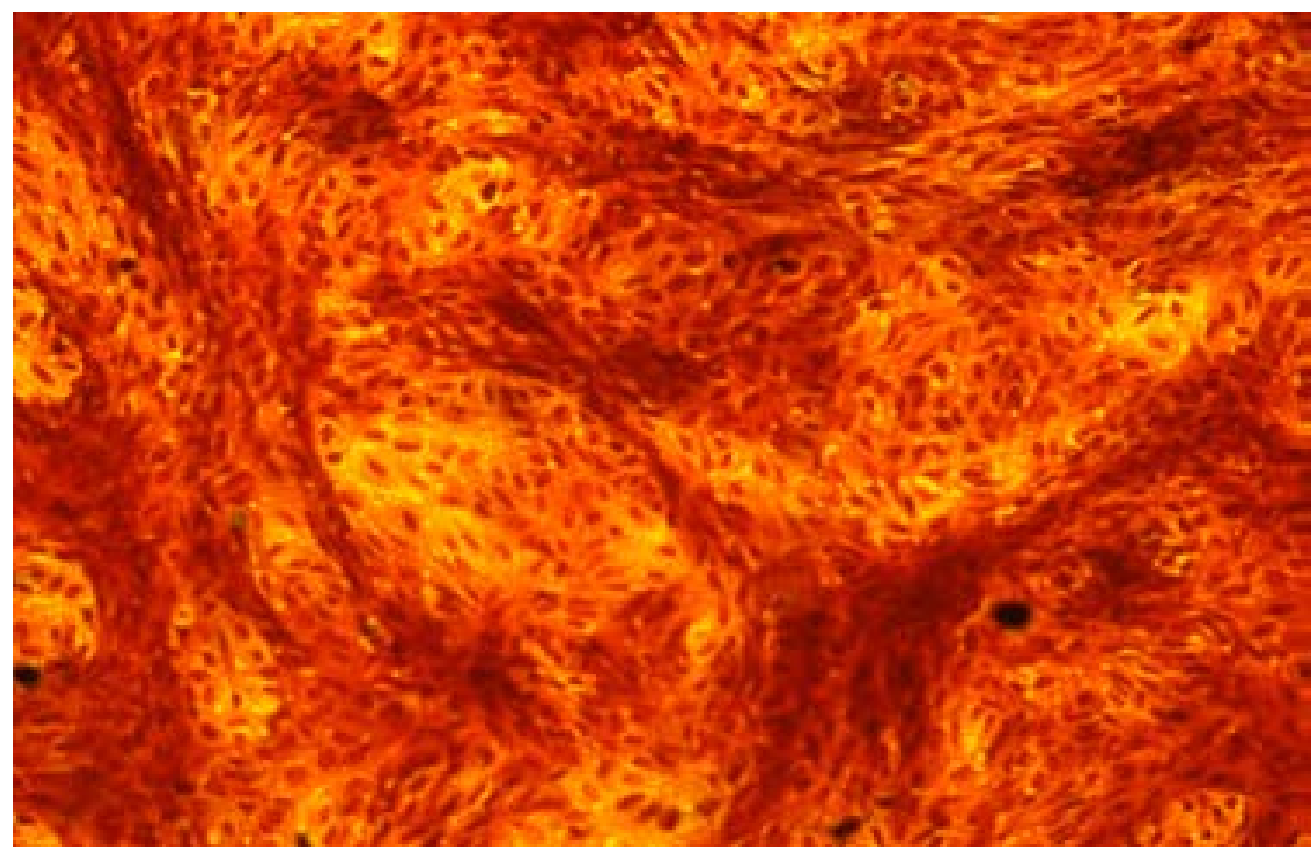

Figure 1 (a) 


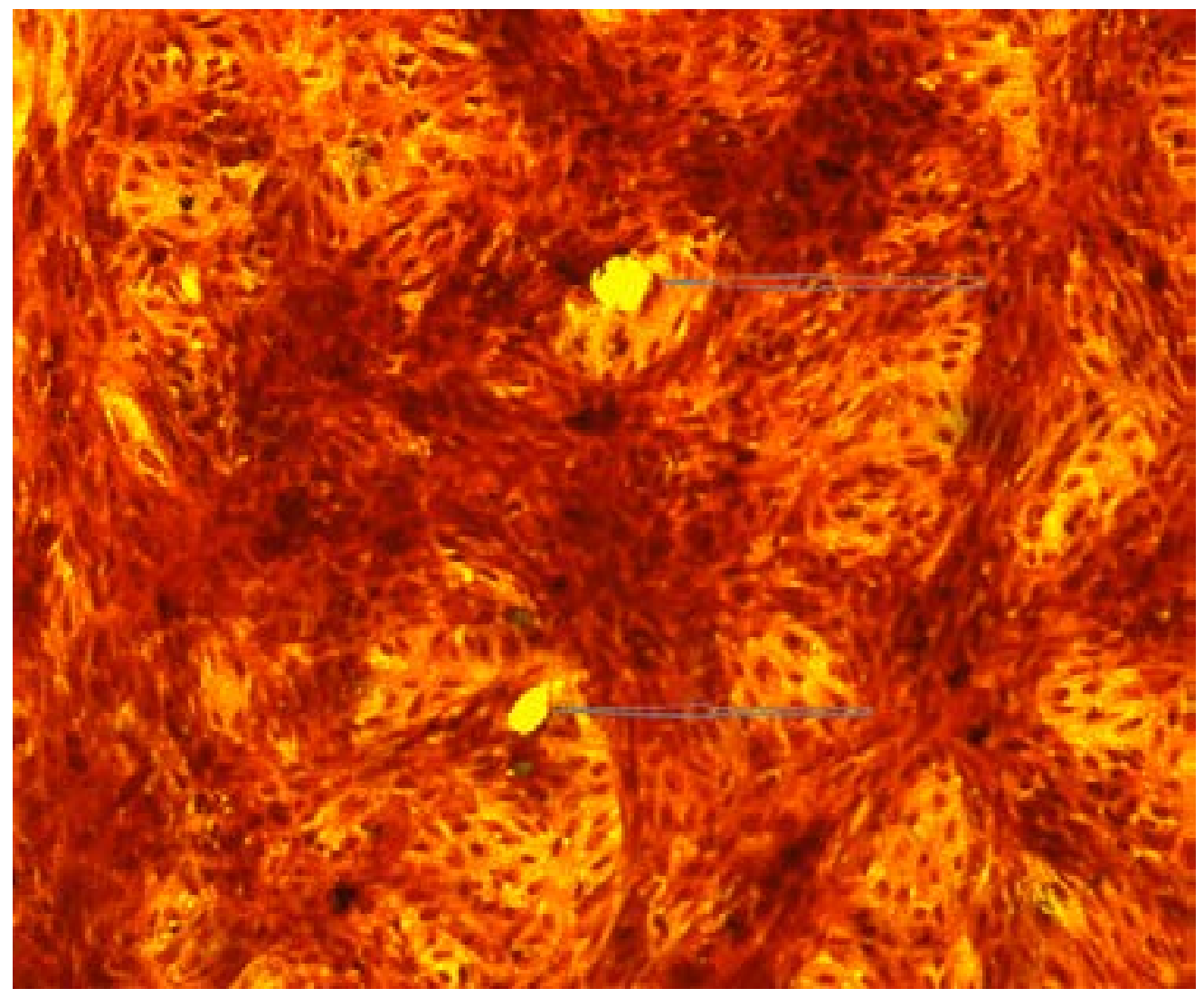

Figure 1 (b)

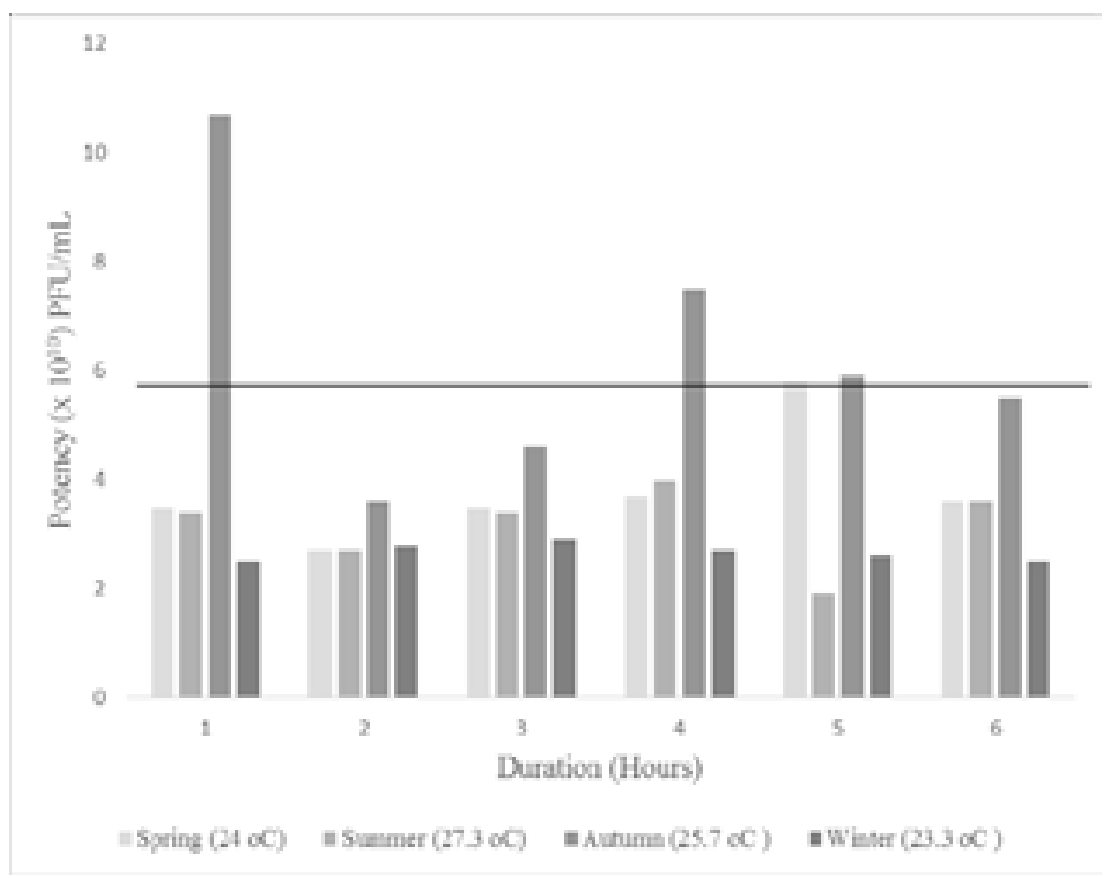

Figure 2 


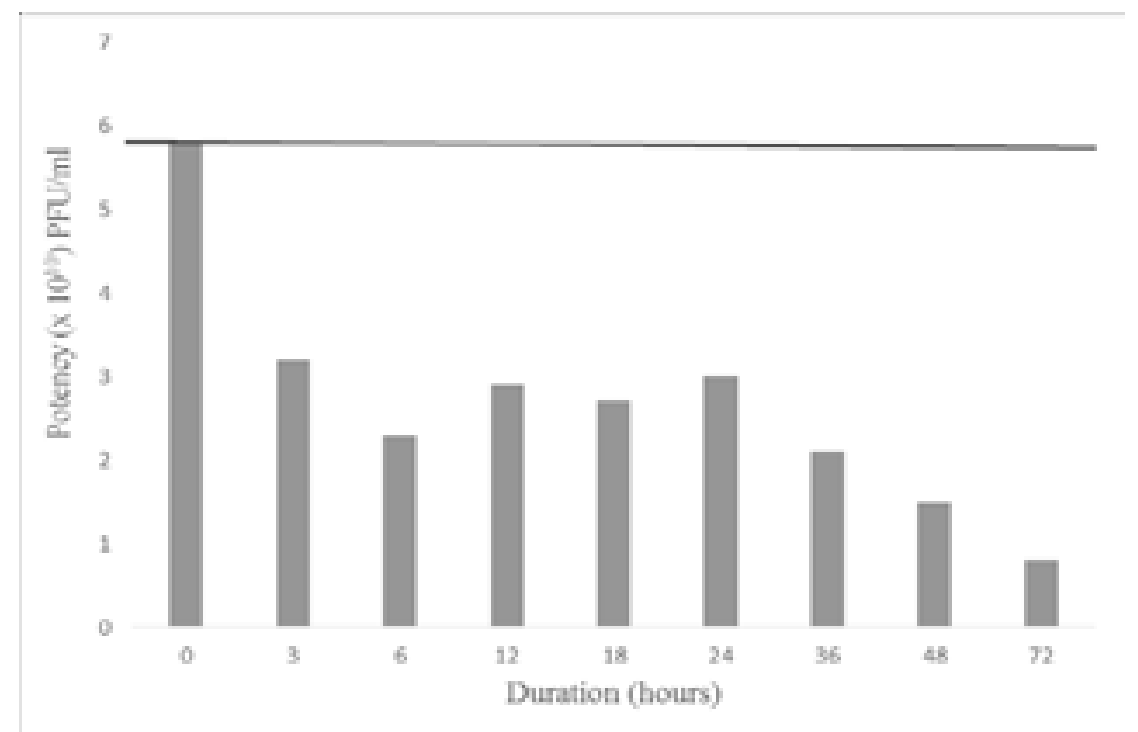

Figure 3

\section{Discussion}

The possibility of the Rotarix ${ }^{\circledR}$ vaccine exposure to non-optimal temperatures was considered as a factor responsible for the reduced effectiveness of this rotavirus vaccine in low income countries. This vaccine remained potent after exposure to the seasonal temperatures for 6 hours. Although the potencies at the different seasonal temperatures were lower than the pre-exposure potency except at autumn temperature at some of the time points. The observed higher potency at the 1, 4 and 5 hour time point of this temperature in comparison to the pre-exposed vaccine potency may be explained by a higher quantity of vaccine virus in the vials used at these time points. In addition, exposure to $+40^{\circ} \mathrm{C}$ for 72 hours as well as to $-20^{\circ} \mathrm{C}$ and $-80^{\circ} \mathrm{C}$ for 12 hours was well tolerated. These findings correlate with a similar finding in India where a recently licensed thermostable live attenuated Rotavirus vaccine (ROTASIIL ${ }^{\circledR}$ ) was found to withstand temperatures as high as $40^{\circ} \mathrm{C}$ and $55^{\circ} \mathrm{C}$ for long- and short-term exposure respectively ${ }^{15}$. In addition, the study reported that the vaccine was able to tolerate a temperature shock of being thawed from $-200 \mathrm{OC}$ to a temperature of $42^{\circ} \mathrm{C}^{15}$.

The mechanism for the reduced effectiveness of the Rotarix ${ }^{\circledR}$ vaccine in middle and low income countries ${ }^{16}$ in contrast to the observed high effectiveness of this vaccine in high income countries ${ }^{17}$ is not completely understood.
Although possible factors driving these variations in vaccine effectiveness have previously been reported ${ }^{18}$. Viral, environmental and host factors were identified as possible determinant of protection elicited by this vaccine ${ }^{18}$. Protection from diverse rotavirus strains including non-vaccine genotypes has been reported as a significant characteristic of this vaccine ${ }^{16,19}$. However, the mechanism of this vaccine protection against diverse and emerging rotavirus strain is incompletely understood. Environmental enteropathy, a sub-clinical condition affecting the small intestine of children in low income countries was suggested as a factor influencingvaccine effectiveness ${ }^{20}$. This condition is characterized by chronic exposure to faecal pathogens due to poor sanitation leading to chronic inflammation of the intestine ${ }^{21}$. The presence of maternal antibodies acquired via breast milk has been reported to compromise the effectiveness of the rotavirus vaccine in children $^{22}$. In addition, pre-existing serum immunoglobulin $G(\operatorname{IgG})$ was reported to have an inhibitory effect on the immunogenicity of the rotavirus vaccine ${ }^{23}$.

\section{Limitation of the study}

This study was unable to elucidate reason(s) for the maintained potency of the Rotarix ${ }^{\circledR}$ vaccine after exposure to non-optimal temperatures. In addition, this study only explored the effect of a constant 'adverse' temperature on vaccine potency and not the effect of temperature fluctuations. 


\section{Conclusion}

The stability of theRotarix ${ }^{\circledR}$ vaccine after exposure to diverse temperatures reflecting potential storageor transit temperatures in some middle- and low-income countries was highlighted in this study. It will be interesting to evaluate the effect of non-optimal temperatures on the vaccine when exposed for a longer period above the time point in our study. Further exploration is needed to draw a firm conclusion on the stability of the Rotarix ${ }^{\circledR}$ vaccine post exposure to more non-optimal temperatures. This is the only independent study on thermostability of the monovalent Rotarix ${ }^{\circledR}$ vaccine.

\section{Conflict of interest}

None declared.

\section{References}

1. Mapaseka SL, Dewar JB, van der Merwe L, Geyer A, Tumbo J, Zweygarth M, et al. Prospective Hospital-Based Surveillance to Estimate Rotavirus Disease Burden in the Gauteng and North West Province of South Africa during 2003-2005. J Infect Dis [Internet]. 2010 Sep 1 [cited 2018 Oct 11];202(S1):S131-8. Available from: https://academic.oup.com/jid/article-lookup/doi/10.1086/653558 2. Steele AD, Peenze I, de Beer MC, Pager CT, Yeats J, Potgieter N, et al. Anticipating rotavirus vaccines: epidemiology and surveillance of rotavirus in South Africa. Vaccine [Internet]. 2003 Jan 17 [cited 2018 Jan 22];21(56):354-60. Available from: http://www.ncbi.nlm.nih. gov/pubmed/12531632

3. Steele AD, De Vos B, Tumbo J, Reynders J, Scholtz F, Bos P, et al. Co-administration study in South African infants of a live-attenuated oral human rotavirus vaccine (RIX4414) and poliovirus vaccines. Vaccine [Internet]. 2010 Sep 7 [cited 2018 Jan 22];28(39):6542-8. Available from: https://www.sciencedirect.com/science/article/ pii/S0264410X08011328?via\%3Dihub

4. Steele AD, Glass R. Rotavirus in South Africa: From discovery to vaccine introduction. South African J Epidemiol Infect [Internet]. 2011 Jan 15 [cited 2018 Jan 24];26(4):184 90. Available from: https://www.tandfonline.com/doi/ full/10.1080/10158782.2011.11441448

5. Groome M. Rotavirus vaccination in reducing diarrhoeal disease in Africa. [Internet]. World Immunization week. 2015. Available from: . www.nicd.ac.za/assets/ files/Immunization day2015_Groome.pdf
6. National Institute of Communicable Diseases. Communicable Diseases Communiqué. Commun Dis Commun [Internet]. 2013;12(7). Available from: http://www.nicd.ac.za/assets/files/ NICD-NHLS\%25\%0A20Communicable\%2520Disease $\% 2520 \mathrm{Communiqu} \% 25 \% 0$ AC $3 \% 25 \mathrm{~A} 9$ June $\left.\% 25202013 \_\% 25281 \% 2529 . p d f \% 0 A\right)$

7. Matthias DM, Robertson J, Garrison MM, Newland $\mathrm{S}$, Nelson C. Freezing temperatures in the vaccine cold chain: a systematic literature review. Vaccine [Internet]. 2007 May 16 [cited 2018 Oct 15];25(20):3980-6. Available from: http://www.ncbi.nlm.nih.gov/pubmed/17382434 8. Milstien JB, Galazka AM, Kartoglu U, Zaffran M. Temperature sensitivity of vaccines. World Heal Organ Dept Immunization, Vaccines Biol. 2006;1-58.

9. Boros CA, Hanlon M, Gold MS, Roberton DM. Storage at $-3^{\circ} \mathrm{C}$ for $24 \mathrm{~h}$ alters the immunogenicity of pertussis vaccines. Vaccine [Internet]. 2001 May 14 [cited 2018 Oct 11];19(25-26):3537-42. Available from: https:// www.sciencedirect.com/science/article/pii/S0264410X01000639?via\%3Dihub

10. Ho MM, Mawas F, Bolgiano B, Lemercinier X, Crane DT, Huskisson R, et al. Physico-chemical and immunological examination of the thermal stability of tetanus toxoid conjugate vaccines. Vaccine [Internet]. 2002 Oct 4 [cited 2018 Oct 11];20(29-30):3509-22. Available from: https://www.sciencedirect.com/science/article/pii/ S0264410X02003420?via\%3Dihub

11. Bolgiano B, Mawas F, Yost SE, Crane DT, Lemercinier X, Corbel MJ. Effect of physico-chemical modification on the immunogenicity of Haemophilus influenzae type b oligosaccharide-CRM(197) conjugate vaccines. Vaccine [nternet]. 2001 Apr 30 [cited 2018 Oct 11];19(2324):3189-200. Available from: http://www.ncbi.nlm.nih. gov/pubmed/11312015

12. Diminsky D, Moav N, Gorecki M, Barenholz Y. Physical, chemical and immunological stability of $\mathrm{CHO}$-derived hepatitis B surface antigen ( $\mathrm{HBsAg}$ ) particles. Vaccine [Internet]. 1999 Aug 20 [cited 2018 Oct 11];18(12):3-17. Available from: http://www.ncbi.nlm.nih.gov/ pubmed/10501230

13. South African Weather Service. Publications [Internet]. [cited 2018 May 23]. Available from: http://www. weathersa.co.za/climate/publications

14. Smith EM, Estes MK, Graham DY, Gerba CP. A Plaque Assay for the Simian Rotavirus SA11.J Gen Virol 
[Internet]. 1979 Jun 1 [cited 2018 Oct 11];43(3):513-9. Available from: http://jgv.microbiologyresearch.org/ content/journal/jgv/10.1099/0022-1317-43-3-513

15. Naik SP, Zade JK, Sabale RN, Pisal SS, Menon R, Bankar SG, et al. Stability of heat stable, live attenuated Rotavirus vaccine (ROTASIIL®). Vaccine [Internet]. 2017 May 19 [cited 2018 Oct 11];35(22):2962-9. Available from: https://www.sciencedirect.com/science/article/ pii/S0264410X17304991?via\%3Dihub

16. Groome MJ, Page N, Cortese MM, Moyes J, Zar HJ, Kapongo CN, et al. Effectiveness of monovalent human rotavirus vaccine against admission to hospital for acute rotavirus diarrhoea in South African children: a case-control study. Lancet Infect Dis [nternet]. 2014 Nov 1 [cited 2018 Jan 22];14(11):1096-104. Available from: http:// www.ncbi.nlm.nih.gov/pubmed/25303843

17. Staat MA, Payne DC, Donauer S, Weinberg GA, Edwards KM, Szilagyi PG, et al. Effectiveness of Pentavalent Rotavirus Vaccine Against Severe Disease. Pediatrics [Internet]. 2011 Aug 1 [cited 2018 Jan 22];128(2):e26775. Available from: http://www.ncbi.nlm.nih.gov/ pubmed/21768317

18. Clarke E, Desselberger U. Correlates of protection against human rotavirus disease and the factors influencing protection in low-income settings. Mucosal Immunol [Internet]. 2015 Jan 3 [cited 2018 Jan 22];8(1):1-17. Available from: http://www.nature.com/articles/mi2014114 19. Msimang VMY, Page N, Groome MJ, Moyes J, Cortese MM, Seheri M, et al. Impact of Rotavirus Vaccine on Childhood Diarrheal Hospitalization After Introduction Into the South African Public Immunization Program. Pediatr Infect Dis J [Internet]. 2013 Dec 1 [cited 2018 Jan 22];32(12):1359-64. Available from: http://content. wkhealth.com/linkback/openurl?sid=WKPTLP:landingpage\&an $=00006454-201312000-00022$

20. Campbell DI, Murch SH, Elia M, Sullivan PB, Sanyang MS, Jobarteh B, et al. Chronic T Cell-Mediated Enteropathy in Rural West African Children: Relationship with Nutritional Status and Small Bowel Function. Pediatr Res [Internet]. 2003 Sep 1 [cited 2018 Jan 22];54(3):30611. Available from: http://www.nature.com/doifinder/10.1203/01.PDR.0000076666.16021.5E

21. Neto UF, Martins MC, Lima FL, Patricio FR, Toledo MR. Asymptomatic environmental enteropathy among slum-dwelling infants. J Am Coll Nutr [nternet]. 1994 Feb [cited 2018 Jan 22];13(1):51-6. Available from: http:// www.tandfonline.com/doi/abs/10.1080/07315724.1994 .10718371

22. Moon S-S, Wang Y, Shane AL, Nguyen T, Ray P, Dennehy $\mathrm{P}$, et al. Inhibitory effect of breast milk on infectivity of live oral rotavirus vaccines. Pediatr Infect Dis J [nternet]. 2010 Oct [cited 2018 Jan 22];29(10):919-23. Available from: http://www.ncbi.nlm.nih.gov/pubmed/20442687 23. Moon SS, Groome MJ, Velasquez DE, Parashar UD, Jones S, Koen A, et al. Prevaccination Rotavirus Serum IgG and IgA Are Associated with Lower Immunogenicity of Live, Oral Human Rotavirus Vaccine in South African Infants. Clin Infect Dis. 2016;62(2):157-65. 